\title{
Under-Consumption and the Accumulation Motive
}

Thomas I. Palley

Department of Economics

New School for Social Research

New York, NY 10003

My thanks to Sam Bowles for helpful suggestions which have greatly improved the quality of the paper.

Abstract 
This paper presents a theory of individual behavior in which the drive to accumulate wealth is a critical motive behind economic action. The suggested theory is fully consistent with the NeoClassical approach to choice, subject only to displacing the traditional hedonistic interpretation. When this theory of individual behavior is placed in the context of a self-interest private property economy in which individuals accumulate wealth in the form of financial claims(intermediated accumulation) and firms maximize profits, it generates a logical explanation of the causes of effective demand failures.

JEL reference: E0, E2

Keywords: Under-Consumption, Wealth Accumulation, Intermediated Accumulation.

\section{Introduction}

The theory of under-consumption has a long and distinguished pedigree within the history of economic thought, yet within current mainstream economic theory it has all but dropped by the wayside. Although contemporary economists may talk of the problem of deficient demand relative to potential production, the reasoning is now of an entirely different social and political complexion. This paper seeks to examine how this subtle intellectual transformation was effected, and how the constructions of modern microeconomic theory preclude the earlier view of underconsumption. The paper then discusses how this earlier view can be re-instated within the modern Neo-Classical utility maximization framework. |

It should be emphasized at the outset that the goal of the paper is not to argue that bouts of under-consumption represent a frequent problem within contemporary economies: indeed the opposite may be true. Rather the argument is that excavating the foundations of this earlier view provides a superior understanding of the behaviors that constitute economic action, and helps understand many of the major institutional developments that have characterized capitalist economies over the last fifty years. Moreover, these developments may themselves explain why 
under-consumption has not been a problem in recent history, but with them come a potential new set of economic problems.

At a deeper level the paper challenges the fundamental vision which has driven modern theory. This vision which derives from Adam Smith's metaphor of the invisible hand, maintains that the voluntary pursuit of individual economic self-interest is ultimately consistent, subject only to establishing the right vector of prices. Within contemporary macroeconomics this vision is shared by both New Classicals and Neo-Keynesians, albeit that the latter emphasize the "arthritic" aspects of the invisible hand as manifested in price rigidities and co-ordination failures. In place of this harmonious vision the paper presents a psychological basis to economic action that potentially generates insufficient demand for output. This outcome is unrelated to the issue of market failure, but rather derives from the primitive psychological goals that are the impulse to economic action.

II. Under-Consumption and the Keynesian Revolution: A Brief Retrospective in the History of Thought

The Great Depression of the 1930's marks the single greatest crisis in the economic history of the developed capitalist economies. To many at the time, economic events seemed to confirm the theories of under-consumption developed by the early Classical economists of the 18th and 19th centuries. Yet, paradoxically, mainstream economic thought emerged from this traumatic experience purged of these very theories.

In many respects it is ironic that this purging of the theory of under-consumption can be attributed to the Keynesian Revolution and its intellectual successes, since Keynesian theory emphasized the importance of the demand for output in explaining the level of economic activity. Despite having this profound similarity with theories of under-consumption, Keynesian economics 
radically transformed the representation and social perception of the problem. Whereas Classical under-consumption theory had always been viewed with suspicion, and interpreted as antagonistic toward the dominant ideology and order, the Keynesian system was viewed (by most) as free of these subversive implications. However, as is argued below, this benign position was only obtained by adopting an intellectual framework that ultimately invited the theoretical deconstruction and discrediting of the Keynesian model, and the restoration of Say's Law and the economics that Keynes sought to dispel.

The transformation wrought by Keynes is evident in the very language of the General Theory which restated the problem in the technical terms of aggregate demand. This literary transformation served to avoid the political and ideological conflicts which had surrounded theories of under-consumption. In the face of the evident wants of many, explaining unemployment and its accompanying human waste as the result of under-consumption invited cries for radical change in the distribution of income and the social structure. By restating the problem in terms of aggregate demand, Keynesian theory successfully distanced itself from the theories of the Classical underconsumptionists. In doing so it avoided becoming emeshed in the political controversies surrounding socialism. In place of the public ownership of the means of production, the Keynesian system proposed a new solution to the problems of capitalism captured by Lerner's (1951, p. 3-7) metaphor of the economy as a car travelling down the highway, with the government in the driver's seat and fiscal policy serving as the steering wheel. For the most part this new apolitical representation was widely accepted, though Hayek (1944) is noteworthy for his sustained insistence on the deeper political implications of Keynesian theory.

The new language of macroeconomics pioneered by Keynes readily fitted in with the development of economics as a profession. In common with other professions, the study of 
economics in the 20th century has been marked by the progressive development of professional boundaries and identities. I These developments have served to confer authority and control on the members of the profession, warranting their knowledge claims and disenfranchising the voice of non-members. Part of this movement has involved the development of professional languages accessible only to the members of the profession, and the General Theory with its new vocabulary of macroeconomics was well adapted to this secular trend. In this connection, the widespread adoption of mathematics as a representational device may also be interpreted as part of this trend, and it is noteworthy that the General Theory was considered a mathematically sophisticated text at the date of its publication. While conferring social power on professional economists, these linguistic developments also depoliticized the subject matter of economics: applied to the Keynesian Revolution, effective demand and the algebra of $\mathrm{C}+\mathrm{I}+\mathrm{G}$ now displaced the theory of under-consumption.

While the apolitical and technical language of the General Theory facilitated the Keynesian Revolution, its triumph was the result of Keynes' theoretical innovations and his provision of a socially acceptable explanatory framework for addressing the catastrophic events of the 1930's. These innovations included the liquidity preference theory of interest rates, the liquidity trap, and Keynes' extensive treatment of expectations, and the theory of investment. With his Marshallian background, the theoretical structure of the analysis was in the spirit of market equilibrium. The economy was represented as a set of markets, and the nature of equilibrium in each market was then examined. The instability of entrepreneurial expectations combined with the existence of interest rate floors, then opened the possibility that interest rates might be unable to ensure a level of demand sufficient for full-employment. 
This representation of the economy was more than just a matter of theoretical refinement of subject matter and technique $\mid$ : it marked a decisive break with Classical analysis. For Classical economists the theory of distribution had been at the fore of their explanations of the level of economic activity. The problems of capitalism were definitively linked to the question of distribution, which itself was the source of the problem of effective demand. This position is captured by Rodbertus (1949, p. 249) who writes:

"This circumstance is that when the distribution of the national product is left to itself, certain circumstances connected with the development of society produce this effect: that with increasing productiveness of the labor of society, the wages of the laboring class become an ever smaller portion of the national product.

...It would be equally clear that on account of that circumstance the main channel of sale of internal and consequently of the entire national trade, that is, the purchasing power of four-fifths or five-sixths of society, does not expand in proportion to the progressive production, but rather simultaneously contracts in like proportion, from which it be just as easy to demonstrate the necessity of glut."

The Classical representation of the macro economy therefore held capitalist economies to be fundamentally inconsistent, being marked by tendencies to generate patterns of distribution inconsistent with full-employment.

Unlike the Classicals, Neo-Keynesian analysis of the macroeconomic problem did not identify Capitalism as a potentially inconsistent form of economic organization. Rather the problem was represented as one of "market failure" concerning the adjustment of interest rates and prices. Keynes' analysis therefore radically shifted the focus of debate within macroeconomics to 
problems of price rigidity and inter-temporal co-ordination failure. The flavor of the new analysis is captured by the following passage from the General Theory (p. 210-11).

An act of individual saving means--so to speak-- a decision not to have dinner today. But it does not necessitate a decision to have dinner or to buy a pair of boots a week hence or a year hence or to consume any specified thing at any specified date. Thus it depresses the business of preparing today's dinner without stimulating the business of making ready for some future act of consumption. It is not a substitution of future consumption-demand for present consumptiondemand,--it is a net diminution of such demand....If saving consisted not merely in abstaining from present consumption but in placing simultaneously a specific order for future consumption, the effect might indeed be different. For in that case the expectation of some future yield from investment would be improved, and the resources released from preparing for present consumption would be turned over to preparing for the future consumption....

The implications of Keynes' analysis were quickly picked up. Pigou (1943) challenged Keynes' claim to an underemployment equilibrium showing that price deflation would serve to restore aggregate demand through a wealth effect operating on money balances. Modigliani (1944) extended this line of inquiry identifying rigid nominal wages as the culprit, since nominal wage rigidity explained why prices did not fall. Henceforth, labor market failure was identified as the principle source of the macroeconomic problem, and labor was now held to be implicitly responsible for the problem of unemployment. Such a line of reasoning, all be it with ever more sophisticated stories explaining price and wage rigidity, continues to be the approach of contemporary macroeconomics. In writing the General Theory Keynes had intended a decisive intellectual break with the past. The Keynesian Revolution achieved such a break, but it was not a 
break with the full-employment equilibrium theory of his rival, A.C. Pigou: rather it was a break with the Classical tradition and the theory of under-consumption.

\section{Reinterpreting Scarcity}

From its conception modern economics has proclaimed scarcity to be the universal condition which provides the raison d'etre for economic inquiry. Neo-Classical theory, which dominates contemporary economic theory, places a particular interpretation on scarcity, justifying it in terms of an unlimited demand for consumption by individuals. The formal embodiment of this interpretation within the constructs of utility theory involves the insatiability assumption regarding individual preferences, which ensures that marginal utility is always positive. This apparently innocent technical assumption, which is quickly foisted upon the entering student to be thereafter taken for granted, has enormous ramifications for macroeconomic theory. This is because if economic agents have insatiable consumption demands, the notion of primally deficient demand as the first cause of unemployment becomes problematic. Instead the cause of unemployment must be located in missing markets, price-wage rigidities, or information imperfections, all three of which force a departure from the benchmark of full-information perfectly competitive markets, thereby preventing the mutual realization of trading plans.

The Neo-Classical theory of utility maximization is a philosophically appealing framework for addressing human action. With simplicity and ease it resolves the difficult theoretical problem of agency, providing a framework for understanding and addressing action and choice by individuals. The appeal of the approach is clear and common-sensical: where people make conscious choices, they do so with an eye to their perceived self-interest. It is important not to overstate the claims of the theory. The theory only requires that choices be in one's perceived self- 
interest, where these perceptions are subjective rather than objective. This leaves plenty of room for ex-post regret. Moreover, the emphasis on perceived self-interest leaves room for the possibility of persuasion, and for the possibility of mistakes arising from incorrect information or lack of experience. In choices involving computation there is also room for mistakes if computational abilities are limited. Furthermore, these mistakes can persist until they are somehow brought to the attention of the person making the choice: however, once recognized, the pursuit of self-interest would require that they be remedied (after taking into account any resource cost to remedying them). It should also be noted that the theory only applies to situations in which intentional choice is exercised: as such it does not apply to actions made out of habit or reflex, though it is then interesting to inquire how habits are initially formed, and how persons can be persuaded to change their habits. Finally, the theory makes no contribution regarding why people get satisfaction from particular choices and not from others. This opens the all important question of "tastes," and how they are formed.

If it is hard to disagree with the theoretical claim that freely exercised conscious choice is directed toward enhancing one's perceived well-being, it is not difficult to challenge the "hedonistic" representation of this claim (which dominates mainstream economic thought) in which well-being derives from the pursuit of private consumption. The current paper questions this claim, and replaces it with the claim that human action is motivated both by the pursuit of consumption and the desire to accumulate wealth. I Such a modification then serves to reopen the problem of under-consumption in ways that are effectively blocked by existing hedonistic representations of the Neo-Classical theory of choice.

Questioning the existing consumption based interpretation of human motivation is problematic. It is problematic not only because it involves an investigation of the inner realm of 
mental life, but also because consumption is the officially sanctioned and publicly articulated goal of the American dream. In all corners of our society images of consumption and affluent living dominate our representations and interpretations of economic life, and on the surface of things consumption appears to be the self-evident goal of economic action. For geologists, rare events such as large earthquakes provide the most useful evidence for understanding the physical structure of the earth's crust. For economists a similar principle may well apply. In this connection each year Forbes magazine lists the four hundred wealthiest individuals in the United States. In 1988, topping the list was Sam Moore Walton, the founder of the Wal-Mart chain of stores, whose estimated net worth was 6.7 billion dollars. At the bottom of the list was Gerald Douglas Hines whose net worth was 225 million dollars. For each of these four hundred persons, their existing wealth far exceeds their lifetime consumption stream, yet many continue to seek ever greater wealth. Prima facie, such behavior therefore challenges the claim that maximizing personal lifetime consumption constitutes the sole psychological drive behind economic action.

The response of existing Neo-Classical theory to such behavior is to refine the description of the individual to include inter-generational altruism. Well-being is therefore made to depend on own consumption levels plus the utility of future generations (Barro, 1974). This description is captured by a utility function of the following form

(1) $\quad \mathrm{Ut}=\mathrm{U}(\mathrm{Ct}, \mathrm{Ut}+1)$

where Ut $=$ lifetime well-being of generation $\mathrm{t}$.

$\mathrm{Ct}=$ vector describing lifetime consumption pattern of generation $\mathrm{t}$.

$\mathrm{Ut}+1$ = lifetime well-being of generation $\mathrm{t}+1$. 
Generation $\mathrm{t}$ is thus implicitly concerned with the consumption patterns of all future generations, and therefore has an implicit infinite horizon with regard to its economic decisions. This specification therefore maintains the hedonistic interpretation of economic action, while explaining wealth accumulation in excess of lifetime consumption through inter-generational altruism.

One obvious challenge to this refined theory of hedonistic behavior concerns why individuals leave bequests in a world in which real per capita income is rising over time. Of course one response is to make ad hoc assumptions about the parameters of the utility function (tastes), and assume that persons get greater utility from the consumption of future generations. However, this treatment raises doubts concerning another critical element of existing theory, namely the Fisherian theory of interest rates. This is because Fisherian theory relies on positive rates of time preference to explain interest rates, but the validity of this assumption is questionable if at the same time individuals get greater well-being from the consumption of future generations.

The above maneuverings of contemporary Neo-Classical theory were long ago anticipated by Thorstein Veblen (1949, p. 347) who wrote of the hedonistic version of marginal utility theory

The hedonistically presumed final purchase of consumable goods is habitually not contemplated in the pursuit of business enterprise. Business men habitually aspire to accumulate wealth in excess of the limits of practicable consumption and the wealth so accumulated is not intended to be converted by a final transaction of purchase into consumable goods or sensations of consumption. Such commonplace facts as these, together with the endless web of business detail of a like pecuniary character, do not in hedonistic theory raise a question as to how these conventional aims, ideals, aspirations, and standards have come into force or how they affect the scheme of life in business or outside of it; they do not raise those questions because such questions cannot be 
answered in the terms which the hedonistic economists are content to use, or indeed, which their premises permit them to use. The question which arises is how to explain the facts away: how theoretically to neutralize them so that they will not have to appear in the theory, which can then be drawn in direct and unambiguous terms of rational hedonistic calculation.

The current paper addresses these failings, and provides an alternative explanation of the psychological basis of economic action. This is now represented in terms of the desire for consumption and the desire to accumulate wealth, which implies a utility function of the form

$$
\mathrm{Ut}=\mathrm{U}(\mathrm{Ct}, \mathrm{Wt})
$$

where $\mathrm{Wt}=$ vector describing lifetime wealth pattern of generation $\mathrm{t}$.

Wealth is therefore entered as a direct argument in the utility function, representing the operation of an "accumulation motive" which is a psychological drive to economic action that is distinct from and independent of the "consumption motive". Just as the desire for consumption is ultimately the desire for the physiological and psychological satisfactions derived from the act of consuming, so too the desire to accumulate wealth should be understood in terms of the psychological needs it satisfies. Prime amongst those needs satisfied by the accumulation of wealth are the acquisition of power and the fulfillment of a sense of achievement. Professional psychologists studying personality (see McClelland, 1985) have identified the desire for power and achievement as two critical attributes in personality, while the philosopher Bertrand Russel (1938, p. 11) thought that power and glory were the highest aspirations of mankind, and about which he wrote "Of the infinite desires of man, the chief are the desires for power and glory." Within the context of contemporary society the accumulation of wealth satisfies these psychological drives: through the market economy it confers power because of the command it provides over resources and labor, while the accumulation of riches is esteemed as one of the highest forms of achievement. 
The above model of individual behavior may be formalized in a simple two-period Fisherian model. Each individual seeks to solve the following program

(3) $\operatorname{Max} V=U(c 1, w 1)+U(c 2, w 2) /(1+d)$

$\mathrm{c} 1, \mathrm{c} 2, \mathrm{w} 1, \mathrm{w} 2$

subject to $\mathrm{y} 1=\mathrm{c} 1+\mathrm{w} 1$

$$
\begin{aligned}
& \mathrm{c} 1+\mathrm{c} 2+\mathrm{w} 2=\mathrm{y} 1+\mathrm{y} 2 \\
& (1+\mathrm{r})(1+\mathrm{r}) \quad(1+\mathrm{r}) \\
& \mathrm{c} 1>0, \mathrm{c} 2>0, \mathrm{w} 2>0, \mathrm{w} 10
\end{aligned}
$$

where $\mathrm{ci}=$ consumption in period $\mathrm{i} \quad \mathrm{i}=1,2$

$$
\begin{aligned}
& \text { wi }=\text { wealth in period } \mathrm{i} \quad \mathrm{i}=1,2 \\
& \mathrm{yi}=\text { income in period } \mathrm{i} \quad \mathrm{i}=1,2 \\
& \mathrm{r}=\text { real interest rate } \\
& \mathrm{d}=\text { discount rate }
\end{aligned}
$$

The individual therefore chooses c1, c2, w1, and w2, where w1 may be positive or negative depending on whether an individual borrows or lends in the first period. Note that borrowing gives positive utility because it enables increased period 1 consumption, but in addition to the interest cost there is also a utility cost which derives from the psychological effects of being in debt.

The first order conditions for the lagrangean (L) are

(4a) $\mathrm{dL} / \mathrm{dc} 1=\mathrm{Uc} 1-\mathrm{a} 1-\mathrm{a} 2=0$

(4b) $\mathrm{dL} / \mathrm{dw} 1=\mathrm{Uw} 1-\mathrm{a} 1=0$

(4c) $\mathrm{dL} / \mathrm{dc} 2=\mathrm{Uc} 2 /(1+\mathrm{d})-\mathrm{a} 2 /(1+\mathrm{r})=0$

(4d) $\mathrm{dL} / \mathrm{dw} 2=\mathrm{Uw} 2 /(1+\mathrm{d})-\mathrm{a} 2 /(1+\mathrm{r})=0$

(4e) $\mathrm{dL} / \mathrm{da} 1=\mathrm{y} 1-\mathrm{c} 1-\mathrm{w} 1=0$ 
(4f) $\mathrm{dL} / \mathrm{da} 2=\mathrm{c} 1+\mathrm{c} 2+\mathrm{w} 2+\mathrm{y} 1+\mathrm{y} 2=0$

$$
(1+r)(1+r) \quad(1+r)
$$

where a1 and a2 are the lagrangean multipliers which are positive because of the equality nature of the constraints. Households marginal rates of time substitution are given by

(5) $\mathrm{dc} 2 / \mathrm{dc} 1=-(1+\mathrm{d}) \mathrm{Uc} 1 / \mathrm{Uc} 2=-[1+\mathrm{t}(\mathrm{c} 1, \mathrm{c} 2, \mathrm{w} 1, \mathrm{w} 2, \mathrm{~d})] \quad \mathrm{t}>0$

where the function $t$ denotes the subjective rate of time preference which depends on tastes, and the levels of consumption and accumulation. Note that $d$, the discount rate measures the relative importance of present and future utility, while the ratio Uc1/Uc2 measures the marginal rate of substitution between present and future consumption. Using (4a), (4c), and (5) yeilds

(6) $1+\mathrm{t}=(\mathrm{a} 1+\mathrm{a} 2)(1+\mathrm{r})$

a2

Since a1 and a2 are both positive this implies that $(\mathrm{a} 1+\mathrm{a} 2) / \mathrm{a} 1>1$ which implies that $\mathrm{t}>\mathrm{r}$, so that in equilibrium households' subjective rate of time preference exceeds the interest rate. This result may be understood as follows. In the standard Fisherian model the interest rate is equal to the rate of time preference to compensate households for the psychological cost of delayed consumption. However, now households get utility from the act of saving itself so households need less compensation in the form of interest for delaying consumption. Note that if a1, which measures the marginal utility to current period wealth holding, were zero then the standard Fisherian result would obtain.

The above explanation of the desire for wealth significantly changes the interpretation of savings behavior. Rather than being exclusively for purposes of providing for future consumption, saving now becomes an end in itself. An interesting implication of this is that first period saving can be positive even when real interest rates are negative as can be seen by inspecting equation (6) which 
can still hold when $r<0$. This outcome is not possible in the standard Fisherian model for which the first order condition is $(1+t)=(1+r)$. The logic of the new result is that despite negative real interest rates households are sufficiently compensated for delaying consumption by the utility derived from accumulating. However, though the real interest rate can be negative, in a monetary economy the nominal rate can never be negative. This is because agents always have the option of holding money.

Another implication of the model is that the level of aggregate savings will depend on the strength of the accumulation motive which itself depends on local cultural and historical conditions, and this can help explain both inter-temporal and cross-country variations in savings patterns. The presence of the accumulation motive also explains why households leave bequests, since these now become the final measure of accumulation and are therefore a source of psychological satisfaction in their own right. Lastly, a critical feature of this respecification of utility to include the accumulation motive is that it retains the fundamental problem of scarcity which is at the base of all economic analysis. The desires for power and control, and for achievement and social status, which manifest themselves in the act of wealth accumulation, mean that individuals will engage in a constant struggle for the possession and control of resources. Yet paradoxically, within modern capitalist economies, though scarcity is the universal condition, there can simultaneously exist conditions of deficient demand as a result of under-consumption. It is to this issue we now turn.

IV. Macroeconomic implications of the accumulation motive: toward a new macroeconomics.

The previous section offered a microeconomic interpretation of the accumulation motive which was located within a traditional neo-classical framework. This section analyses some of the 
macroeconomic implications that follow from recognition of the accumulation motive. The fundamental claim is that the accumulation motive is potentially generative of "contradiction" within the structure of capitalism, and this results in periods of less than full-employment and less than full utilization of capacity. However, it is important to recognize that although capitalist economies may be susceptible to contradiction, this does not mean that the forces for contradiction dominate all or even most of the time. Instead, these forces are latent and periodically assert themselves. This process is not subject to modelling in logical time, but rather is one that is embedded in the uneven unfolding of history. Thus there may be periods in which the contradictions of the system repeatedly assert themselves, or there may be periods of prolonged prosperity when the contradictions lie below the surface and are not readily discernable. An example of this latter case is the thirty years of relatively uninterrupted prosperity that followed the end of World War II, during which significant institutional developments(discussed later) succeeded in ameliorating the system's contradictions, and enabled private wealth accumulation to proceed apace with relatively full-employment.

Capitalism is without doubt a powerful and vital form of social organization that has been remarkably successful in effecting production. Self-interest, directed toward personal consumption and private wealth accumulation, serves to motivate economic action, and when placed in a system of market exchange based on private property, it constitutes a powerful force for the development of the means of production.

However, production is not undertaken for its own sake, but rather for purposes of making sales and realizing profits, which can in turn be used to finance consumption or wealth accumulation on the part of business owners. It is at this point that the contradiction inherent in "self-interest private property" capitalism emerges. This is because the accumulation motive, which is a major drive to 
economic action, may simultaneously obstruct the realization of sales. The problem arises because of what may be termed "intermediated accumulation" whereby households accumulate wealth in the form of financial claims(which includes money) rather than real goods. This process of directing income toward acquisition of financial claims may under certain conditions reduce the demand for output, thereby generating a problem of deficient demand. At this stage the behavior of firms, which are the locus of production, enters the picture. Profit maximizing firms are not in the business of producing for production's sake, and rational behavior on their part calls for reduced output and employment in the face of demand shortages. Note that if owners of firms were willing to accumulate wealth in the form of unsold inventory this problem would not arise. In this case profit maximizing firms would be willing to produce, and simply pay over all unsold production as dividends. However, accumulating piles of inventory, which are themselves subject to deterioration, yeilds no utility and is perceived as manifestly irrational by all.

To summarize, the contradiction in the system emerges from the interaction of three features: (i) the accumulation motive, (ii) intermediated accumulation, and (iii) profit maximization by firms , where firms constitute the locus of production. Viewed from a systemic standpoint self-interest private property capitalism has been highly successful in developing the means of production, but it has been far less successful in addressing the problem of wealth accumulation and its potentially attendant problem of insufficient demand.

As mentioned earlier such economies can still experience prolonged periods of prosperity. These are periods when the system takes care of itself, and they are characterized by (i) a high rate of household acquisition of consumer durables and housing, so that wealth accumulation is in the form of real goods and contributes to aggregate demand rather than reducing it, (ii) a coincidence between private desires to accumulate wealth and corporate desires to expand or modernize the 
means of production. In these circumstances firms sell liabilities to households and use the proceeds to finance real investment, so that the accumulaton motive once again, albeit indirectly, promotes aggregate demand.

Considered more abstractly, the problem of deficient demand emerges when households seek to accumulate wealth in the form of non-reproducible items, in which case income flows are diverted from the purchase of produced goods. For our purposes these non-reproducibles include land, existing durables and financial claims, and of course money of which Keynes wrote

"Unemployment develops, that is to say, because people want the moon;-men cannot be employed when the object of their desire(i.e. money) is something which cannot be produced....There is no remedy but to persuade the public that green cheese is practically the same thing and to have a green cheese factory(i.e. a central bank) under public control(GT, p.235)."

Standard descriptions of the economy's structure such as are embodied in the GNP accounts, divide the economy into a market and non-market(household) sector, and it is only activity in the market sector that is counted as part of GNP. The above analysis is suggestive of an alternative framework in which the economy consists of a reproducibles sector(R) and a non-reproducibles sector(NR).6 Contractions of employment then occur when income flows are diverted away from the R sector to the NR sector. However, there are equilibrating factors which mitigate against the contraction. Firstly, activity in the NR sector itself involves transacting(e.g. brokerage) and this generates employment: NR workers may then choose to spend part of their income on R goods. Secondly, sellers of NR items may use part of their sale proceeds to purchase R goods, and this serves to redirect demand to the R sector. Thirdly, increases in the demand for NR items drives up their price relative to R goods, and this serves to shift demand back to the R sector. Of course the 
stabilizing effect of this relative price change depends on the degree of substitutability between $\mathrm{R}$ and NR goods. Fourthly, increased demand for existing financial claims(stocks and bonds) drives up the price of these claims, and lowers their current yeild. Firms can now offer new issues, thereby obtaining investment finance at a lower cost of capital, and this may raise investment expenditures and the demand for R goods.

The above analysis describes some of the macroeconomic implications of the accumulation motive. However, as stated earlier capitalist economies are capable of significant institutional change that can ameliorate the problems posed by the accumulation motive. One such development is the expansion of consumer credit markets, a development which jointly satisfies the desire to accumulate wealth and maintains aggregate demand--- creditor households acquire claims against debtor households, while debtor housedolds use their borrowings to finance new purchases. If the rate of population growth is positive, this gives rise to a steady expansion of aggregate demand since the deflationary effects of repayment of past debts is outweighed by new borrowing. Problems only emerge when population growth slows below its previous levels in which case debt repayment effects may dominate new borrowing.

A second development concerns the expansion of government's role as a consumer of goods and labor services, and as a provider of financial claims. This role was recognized by early keynesians (Tobin,1963) who saw government as stepping in and running a deficit in order to absorb the surpluses of private households.9

A third development concerns the evolution of the modern corporation as described by Galbraith(1967). The modern corporation has identified the constitutional weakness that exists on the demand side, and it therefore seeks to ensure the stable expansion of demand through advertising and product innovation. These measures expand the scope of consumer wants, promote 
the accumulation of consumer durables, and may even contribute to the destruction of existing stocks of consumer durables by encouraging consumers to discard older items.

A fourth and final innovation concerns the management of the firm and its goals(objective function). Earlier, the profit maximizing behavior of firms was identified as part of the problem in maintaining aggregate demand because firms were unwilling to undertake unprofitable investment opportunities. The separation of ownership from control which characterizes the modern corporation enables management to pursue other goals. Though traditionally viewed as a microeconomic phenomena, this change of goals and accompanying change in behavior may have significant macroeconomic consequences. To the extent that managerially controlled firms become consumers of produced goods, where this consumption is chosen to maximize managerial welfare, firms now serve to maintain demand other than through investment expenditure. This suggests the following re-statement of the definition of aggregate demand for a closed economy

(7) $\mathrm{AD}=\mathrm{CH}+\mathrm{CF}+\mathrm{I}+\mathrm{G}$

where $\mathrm{CH}=$ household consumption

$\mathrm{CF}=$ corporate consumption

To the extent that take-overs or stock holders succeed in reigning in managerial expenditures this could be deflationary(though possibly welfare improving).

If the above developments serve to mitigate the problem posed by the accumulation motive, there are also forces that may worsen it. Prime amongst these is income distribution. If the demand for wealth, particularly in the form of financial claims, is increasing in income(a normal good) and has an income elasticity that is increasing in income, then redistributions of income in favor of upper income groups will shift demand toward NR items and reduce demand for R goods, thereby lowering output and employment. Such an outcome is similar to the Cambridge, England approach 
to aggregate demand pioneered by Kaldor(1956), only now there is no appeal to the arbitrary distinction between capitalists and workers.

One final issue concerns the ability of price deflation, brought about by nominal wage deflation, to solve the effective demand problem posed by the accumulation motive. This issue relates to the Pigou effect. Neo-keynesian macroeconomics posits that price level declines are unambiguously expansionary. However, now there are offsetting effects owing to the existence of inside debt, where these debt effects operate on both the demand and the supply sides of the economy. Price level declines make creditors better off and debtors worse off. If debtor households have a lower marginal propensity to accumulate than do the creditor households holding their obligations, price declines are deflationary. With regard to firms, price level declines reduce the ability of firms to fund investment expenditures and managerial consumption. Additionally, firms may be unable to obtain their desired working capital needs, and this imposes an effective supply constraint which also reduces employment and output. Considered together, the existence of inside debt makes it unlikely that price level reductions can solve the problem posed by the accumulation motive. V. Conclusion.

This paper has presented a theory of individual behavior in which the drive to accumulate wealth is a critical motive behind economic action. The suggested theory is fully consistent with the Neo-Classical approach to choice, subject only to displacing the traditional hedonistic representation. When this theory of behavior was placed in the context of a self-interest private property economy in which individuals accumulated wealth through the acquisition of financial claims(intermediated accumulation), and in which production was organized by profit maximizing firms, it provided a logical explanation of effective demand failure. The paper also identified a number of institutional developments that tended to ameliorate the problem of insufficient demand, 
but it also argued that price level deflation did not offer a solution. Lastly, the accumulation motive explained why equilibrium real interest rates could be negative.

\section{References}

Barro, R.J., "Are Government Bonds Net Wealth?" Journal of Political Economy, 82 (November/December 1974): 1095-1117.

Bleaney, M., Underconsumption Theories, New York:International Publishers ,1976.

Devine, J.N.,"Underconsumption, Over-Investment, and the Origins of the Great Depression," Review of Radical Political Economics, 15 (Summer 1983): 1-27.

Fisher, I., "The Debt-Deflation Theory of Great Depressions," Econometrica, 1 (October 1933): 337-357.

Galbraith, J.K., The New Industrial State, Boston: Houghton Mifflin, 1967.

Hayek, F.A., The Road to Serfdom, Chicago: University of Chicago Press, 1944.

Hicks, J.R., and Allen, R.G.D. (1934), "A Reconsideration of the Theory of Value," Economica, 1. Hilferding, R., Finance Capital, New York: Routledge, Kegan, and Paul, 1981.

Kaldor, N., "Alternative Theories of Distribution," Review of Economic Studies, 23 (1955-56): 94100.

Keynes, J.M., The General Theory of Employment, Interest, and Money, Londo:MacMillan, 1936.

Kohn, M., "Monetary Analysis, the Equilibrium Method, and Keynes' General Theory," Journal of Political Economy, 94 (December 1986): 1191-1224.

Lerner, A., Economics of Employment, New York:McGraw-Hill, 1951.

Luxemburg, R., The Accumulation of Capital, New York: Routledge, Kegan, and Paul, 1951.

Malthus, T.R., "A Summary of the Principle of Population," in Introduction to Malthus, D.V. Glass, ed., London:Watts, 1953.

Marshall, A., Principles of Economics, 9th edition, London:Macmillan, 1961.

Marx, K., Capital, F. Engels, ed., New York:International Publishers, 1984. 
McClelland, D., Human Motivation, Glenview, IL: Scott, Foresman, 1985.

Modigliani, F., "Liquidity Preference and the Theory of Interest and Money," Econometrica, 12 (January 1944): 45-88.

Morawski, J.G., and Hornstein, G., "Quandry of the Quacks: The Struggle for Expert Knowledge in American Psychology, 1890-1940," in The Estate of Social Knowledge: Critical Essays in the History of the Human Sciences, ed. J. Brown and D. Van Keuren, Baltimore:Johns Hopkins Press, 1990.

Mummery, A.F., and Hobson, J.A., The Physiology of Industry, New York: Kelley and Millman, 1956.

Pigou, A.C., "The Classical Stationary State," Economic Journal, 53 (December 1943): 343-51.

Ricardo, D., "Principles of Political Economy," in Works of David Ricardo, P. Sraffa, ed., Cambridge University Press, 1951.

Robertson, D.H., "Some Notes on Mr. Keynes' General Theory of Employment," Quarterly Journal of Economics, 51 (November 1936): 168-191.

Rodbertus, K., "Overproduction and Crises," in History of Economic Thought, ed. K.W. Kapp and L.L. Kapp, New York:Barnes and Noble, 1949.

Russel, B., Power: A New Social Analysis, New York:W.W. Norton, 1938.

Tobin, J., "Deficit, Deficit, Whose got the Deficit?" New Republic, 1963.

Tobin, J. and W.Brainard, "Asset Markets and the Cost of Capital" in Economic Progress, Private Values, and Public Policy: Essays in Honor of William Fellner, North-Holland Publishing Co., 1977.

Veblen, T., "The Limitations of Marginal Utility," in History of Economic Thought, ed. K.W. Kapp and L.L. Kapp, New York:Barnes and Noble, 1949.

| The theory has its formal origins in the work of Thomas Malthus (1953). It was then developed by David Ricardo (1951), and finds its most complete expression in the work of Karl Marx (1984). Within the marxian model it is the falling rate of profit that is the source of crisis, and underconsumption results from the attempts of capitalists to restore profits by wage cuts. The German socialist economists such as Hilferding (1981) and Luxemburg (1951) further developed the implications of under-consumption in their theories of finance capital and imperialism, while Hobson and Mummery (1898) were the leading exponents in England. In America the tradition was developed by Veblen (1909), although now it became disguised by his abiding interest in the anthropological characteristics of modern economic systems. Bleaney(1976) provides a review of 
under-consumption theory, while Devine(1983) applies the theory as part of an explanation of the Great Depression.

| This framework is interpreted as a meta-theoretical approach to the problem of agency, under which individual action and choice is explained as the outcome of the pursuit of perceived selfinterest.

| Historians of Economics have been little concerned with these social dimensions to theoretical and professional developments. However, an excellent discussion of such forces at work amongst professional psychologists is contained in Morawski and Hornstein (1990).

| Kohn (1986) has focused on Keynes' adoption of the equilibrium method as the decisive change within the General Theory, and he contrasts Keynes' equilibrium approach with Robertson's (1936) sequence analysis. The equilibrium approach is identified as a special instance of the sequence approach, representing the case where the economy has settled into a repetitive sequence. However, Kohn's objections can be readily reconciled with Keynesian theory, requiring only the correct identification of the sequence in which agents make choices and transact, and the nature of constraints (such as cash-in-advance) which bind those choices. The sequence approach therefore appears to be a qualification of the equilibrium method.

| Marshall (1961, p. 22-23) recognized this motivation to human action, but in the Allen-Hicks (1934) utility revolution of the 1930's consumption came to dominate as the single argument of the utility function.

6.This includes existing financial claims(stocks and bonds) which are discussed later.

9.This effect is disputed by neo-ricardians(Barro, 1974) who maintain that government bonds are not private wealth. 